\title{
Editorial
}

\section{0 método clínico: fundamento da psicopatologia}

Manoel Tosta Berlinck

Se levarmos a sério o significado da palavra psicopatologia - discurso (logos, logia) da paixão, do afeto (pathos) psíquico seremos, imediatamente, remetidos ao método clínico: espaço percorrido a caminho da palavra representante desse sofrimento.

O método assim entendido contém uma lógica que não é formal e se revela pela narrativa construída pelo médico e o paciente na situação clínica.

A psicopatologia é, portanto, discurso resultante de caminho visando um objetivo, ou seja, ela se realiza por meio da prática clínica. A prática clínica é, por sua vez, caminho que se percorre e seu resultado, sempre precário, quando posto em palavra, chama-se psicopatologia.

A prática clínica é social e, nessa perspectiva, só ela é critério de verdade na psicopatologia, pois desencobre o sempre obscuro pathos psíquico procurando um discurso que o represente. Se atentarmos para o fato segundo o qual a paixão, o afeto, revelamse no caminho em direção à palavra-representante do 
sofrimento psíquico, percebemos, então, que o pathos é sempre obscuro, já que não é imediatamente dado a ver.

O mundo humano é, como bem notava Kant em 1773, predominantemente obscuro. As experiências internas não se dão como as externas, em que os objetos aparecem uns ao lado dos outros e são retidos como permanecendo no espaço. O sentido interno vê as relações de suas determinações somente no tempo, portanto, no fluxo, onde não há continuidade da observação, o que, porém, é necessário para a experiência (p. 34).

A ausência de continuidade das representações no mundo interno cria uma contradição observada por Kant (1773):

Ter representações, e, contudo, não ser consciente delas, nisso parece haver uma contradição, pois, como podemos saber que as temos se delas não somos conscientes? Essa objeção já a fez Locke, que também por isso rejeitou a existência de semelhante espécie de representações. No entanto, podemos ser mediatamente conscientes de ter uma representação, mesmo que não sejamos imediatamente conscientes dela. Tais representações se chamam então obscuras, as restantes são claras, e se a sua claridade se estende às representações parciais de um todo delas e à sua ligação, são representações distintas do pensar ou da intuição. (p. 35)

\section{E prossegue o filósofo iluminista:}

Que seja imenso o campo das nossas sensações e intuições sensíveis, isto é, das representações obscuras no ser humano, de que não somos conscientes, ainda que possamos concluir indubitavelmente que as temos; que, ao contrário, as representações claras contenham apenas infinitamente poucos pontos acessíveis à consciência; que, por assim dizer, no grande mapa de nosso espírito só haja poucos lugares iluminados, isso pode nos causar espanto com relação a nosso próprio ser. (p. 35)

Conclui, então, seu raciocínio, com as seguintes palavras:

O campo das representações obscuras é o maior no ser humano... frequentemente jogamos com representações obscuras e temos interesse em ocultar à imaginação objetos desejados ou indesejados; com mais frequência, porém, somos nós mesmos um jogo das representações obscuras, e nosso entendimento não pode se salvar dos absurdos em que é posto pela influência delas, ainda que as reconheça como engano. (p. 36)

Ora, as representações obscuras só vêm a ser claras por meio da prática de se colocar em palavras as representações sobre o mundo interno, e o método clínico a isso se dedica. Descobrir maneiras de pôr em palavra o obscuro é a finalidade mesma do método. Este, por sua vez, por ser psíquico é singular. As- 
sim, o método clínico é sempre singular e não pode ser regido por normas institucionalizadas. É claro que o percorrer desse caminho acaba constituindo uma experiência, ou seja, uma técnica. Esta, porém, não deve se sobrepor à singularidade da situação e do próprio método.

O método clínico, desencobrindo pela palavra o encoberto, revela a verdade sempre provisória, evanescente do afeto: o pathos psíquico. Colocar em representação o pathos é produzir um conhecimento do humano, pois transforma aquilo que é singular e obscuro no que é claro, abrindo oportunidade para o coletivo. Enquanto internas, as representações obscuras são vivências que podem se transformar em experiência, isto é, em representações socialmente compartilhadas.

Que Kant tenha reconhecido a existência do obscuro no humano e o tenha nomeado de inconsciente, não é de se espantar. Afinal, os pensadores, desde a Grécia antiga reconheciam essa condição humana.

O que espanta, entretanto, é Kant ter aberto mão do método e optado por se dedicar exclusivamente ao claro, àquilo que se manifesta imediatamente no humano.

Qual teria sido a concepção de Kant para a palavra? Ou será que ele foi atacado pelo demônio do meio-dia?

O Colóquio Internacional sobre o Método Clínico, promovido pela Associação Universitária de Pesquisa em Psicopatologia Fundamental e realizado na Fundação Escola de Comércio Álvares Penteado - Fecap, em São Paulo, de 4 a 7 de setembro deste ano, visou apresentações de narrativas sobre o método clínico. Ofereceu, assim, uma oportunidade para o caminhar em direção à palavra representativa do pathos psíquico e dar um testemunho do trabalho que é realizado nesse caminhar.

\section{Referências}

Kant, I. (1773). Antropologia de um ponto de vista pragmático. Trad. de Clélia Aparecida Martins. São Paulo: Iluminuras, 2006.

\section{Manoel Tosta Berlinck}

Sociólogo; psicanalista; Ph.D. (Cornell University, Ithaca, N.Y., USA); professor aposentado da Universidade Estadual de Campinas - Unicamp (Campinas, SP, Brasil); professor do Departamento de Psicologia do Desenvolvimento da Faculdade de Ciências Humanas e da Saúde da 
Pontifícia Universidade Católica de São Paulo - PUC-SP (São Paulo, SP, Brasil); professor do Programa de Estudos Pós-Graduados em Psicologia Clínica da Faculdade de Ciências Humanas e da Saúde da Pontifícia Universidade Católica de São Paulo - PUC-SP, onde dirige, desde 1992, o Laboratório de Psicopatologia Fundamental; presidente da Associação Universitária de Pesquisa em Psicopatologia Fundamental - AUPPF (2002 - 2010); editor responsável de Pulsional Revista de Psicanálise e da Revista Latinoamericana de Psicopatologia Fundamental; membro da World Association of Medical Editors - WAME (Associação Mundial de Editores Médicos); diretor da Livraria Pulsional - Centro de Psicanálise e da Editora Escuta (São Paulo, SP, Brasil); autor de Psicopatologia Fundamental (2000) e de Erotomania, com German E. Berrios (2009), entre outros livros e numerosos artigos.

Rua Tupi, 397/103

01233-001 São Paulo, SP, Brasil

Telefax: (011) 3825-8573

e-mail:mtberlin@uol.com.br 